\title{
PRODUCT PATENT REFORM AND ITS IMPACT ON KOREA'S PHARMACEUTICAL INDUSTRY
}

\author{
SUMNER J. LA CROIX \\ University of Hawaii and East-West Center \\ AKIHIKO KAWAURA* \\ O taru U niversity of Commerce
}

\begin{abstract}
Our analysis focuses on the effect of U.S. government pressure on Korea to adopt product patents for chemical and pharmaceutical products. American pressure began in November 1985 and ended with the Korean Legislature's passage of a new patent law in December 1986. We conduct an event study of the effect of the new patent law on the value of Korean pharmaceutical firms listed on the Korea Stock Exchange. Regression analysis shows that the new law induced excess returns of -74 percent over the 14-month analysis period. The results suggest that adoption of stronger patent laws reduced Korea's wealth. [G14, O34]
\end{abstract}

\section{INTRODUCTION}

Since the early 1980s the United States government has urged developing countries to adopt stronger intellectual property rights (IPRs). Among the countries targeted for public pressure were Thailand, Brazil, Indonesia, Singapore, India, and South Korea. European and American pressure also led to the inclusion of traderelated intellectual property rights (TRIPs) as a topic of negotiation in the 1986 Uruguay GATT Round. The 1994 GATT agreement includes TRIPs provisions mandating higher minimum IPR standards.

In this paper we examine the effects of American pressure on Korea during 19851986 to amend its patent laws to allow chemical and pharmaceutical products to be patented. ${ }^{2}$ Up to 1985 Korea's patent law provided protection to new production processes for manufacturing chemicals and pharmaceuticals but not to new chemical and pharmaceutical products. In 1986 the Korean Legislature passed a new patent law allowing chemical and pharmaceutical products to be patented. We use rate of return data from the Korea Stock Exchange for a portfolio of Korean pharmaceutical

*The authors thank Woo Taik Chung, Soon Sik Ju, Kwang Doo Kim, Chung Lee, Mike Manson, Walter Miklius, and Eui Soon Shin for their help and comments. Eric Abdulateef, Shawn Sefret, and A1 Rillo provided able research assistance. Remaining errors are, of course, our responsibility. The authors thank the Program on International Economics and Politics at the East-West Center and the Japan-United States Friendship Commission for their support of our research on the Korean and Japanese pharmaceutical industries.

'Throughout the paper we use "Korea" to mean the "Republic of Korea" or "South Korea." 
companies to determine whether these firms gained from the introduction of pharmaceutical product patents. The empirical results show that the value of the portfolio of pharmaceutical firms decreased markedly in response to the passage of the 1986 patent law. These results indicate that stronger IPRs have the potential to harm some industries in developing countries.

Section 2 examines the general issue of IPRs in developing countries. Section 3 briefly reviews Korean patent law and examines the genesis of the 1986 amendments. Section 4 describes the event study methodology employed to determine whether the change in the patent law generated excess returns for the portfolio of pharmaceutical companies. Section 5 describes the stock market data and identifies the event announcement date. Section 6 presents results from our empirical analysis. Section 7 examines the implications for other developing countries.

\section{DEVELOPING COUNTRIES AND INTELLECTUAL PROPERTY RIGHTS}

Low- and middle-income countries have generally opposed higher minimum IPR standards. Policymakers in developing countries often base their opposition on the expectation that stronger IPRs will reduce their country's wealth, produce politically unacceptable short-run income losses, or concentrate losses on politically influential industries. Economic modelling of the effects of stronger IPRs has provided some support for their concerns. Maskus (1990) constructed a model for computing welfare changes in information-exporting and information-importing countries. He found that the static welfare losses to information-importing countries are substantial under a wide variety of parameter specifications and that overall static world welfare declines in all simulations. Maskus and Konan's (1994: 426) empirical analysis found that stronger IPRs are not associated with higher levels of foreign investment or with higher levels of welfare for the country strengthening its IPRs. They concluded that "it is impossible to say much about the magnitudes of expected welfare changes from policy strengthening or harmonization without significantly greater information about initial market structures and conduct."

La Croix (1992) argues that a wealth-maximizing government will choose to strengthen its IPRs when the decision maximizes national wealth. In many cases, this means that a government will delay adoption of stronger IPRs until some domestic firms are capable of developing creative works that can be traded internationally. When the decision is framed in this manner, the question for most countries is not whether but when they will adopt stronger IPRs. Government adoption of stronger IPRs is sometimes delayed by the incentives facing public officials and by pressures from organized interest groups. First, politicians usually have short time horizons. Stronger IPRs are often accompanied by short-run income losses due to the time required for individuals and firms to adapt to the new institutional structure. Politicians with short time horizons may heavily discount the long-run dynamic gains from stronger IPRs and delay implementation. Second, firms producing or using (without a license) products 
patented in other countries have incentives to organize and lobby the government to delay strengthening IPRs.

The tendency for governments of developing countries to delay adopting stronger IPRs is often countered by pressures from governments of developed countries to adopt stronger IPRs (La Croix, 1992). Manufacturing firms in developed countries which export patented technologies and patented products lobby their governments to pressure developing country governments to strengthen IPRs immediately, as this would increase profits from licensing fees and exports. The stage is, therefore, set for conflict between different international interest groups and countries.

The conflict over Korean patent laws in 1985-1986 highlights a fundamental question: Would Korea lose wealth if it adopted stronger patent laws? Or, would Korea gain wealth, with the change in patent law being held back by particular interest group and politicians who would lose under the new regime? The question is important, because Korea extensively developed its manufacturing capabilities in the 1970s and early 1980s and could conceivably have reached the point when the chemical and pharmaceutical industries would gain from stronger IPR protection. ${ }^{2}$ However, the strong opposition of the Korean government as well as virtually all Korean chemical and pharmaceutical firms to product patents signalled a probable loss of wealth under the new patent regime. ${ }^{3}$ Our analysis below builds on this preliminary insight by using established econometric methodologies to measure more precisely the gains and losses accruing to Korean pharmaceutical manufacturers.

\section{SHORT HISTORY OF KOREA'S PATENT LAW}

In 1961 Korea established its first formal patent system. ${ }^{4}$ Since the new patent system was not in accord with the Paris Convention, Korea negotiated a series of bilateral agreements with European nations in the early 1960s. In 1981 Korea revised its patent law to conform with the 1967 Stockholm text of the Paris Convention. ${ }^{5}$ The

${ }^{2}$ Between 1970 and 1986 value added in Korean manufacturing increased from US\$1,880 million to US $\$ 29,397$ million (current dollars). Real GDP increased by 9.5 percent per year between 1965 and 1980 and by 8.6 percent per year between 1980 and 1987.

${ }^{3} \mathrm{~A}$ government may adopt stronger protection even if some domestic industries suffer losses if the stronger protection is part of an international treaty, convention, or executive agreement which includes measures benefitting other domestic industries.

${ }^{4}$ See Korean Patent Law, Law No. 950 of Dec. 31, 1961, amended by Law No, 1293 of March 5, 1963, Law No. 2505 of Feb. 8, 1973, Law No. 2658 of Dec. 31, 1973 and Law No. 3325 of Dec. 31, 1980, translated in Office of Patents (1981). See Kim (1992) for a review of Korean intellectual property law.

${ }^{5}$ See South Korean Patent Act, Law No. 3556 of Nov. 29, 1982, translated in Laws of the Republic of Korea, Vol. 50, 4th ed. Korean Legal Center, 1983. Our discussion of the 1982 revision in the patent law relies heavily on West (1983). 
1981 amendments to Korea's patent law contained several significant changes. First, provisions concerning patent revocation for nonworking of a patent were weakened. Second, multiple claims for related inventions could be contained in a single application. Third, foreign nationals (with an address or place of business in Korea) were allowed to apply for patents (through a Korean sponsor) under the Paris Convention's international priority rule. Fourth, patenting of the following categories of products and production processes was prohibited: (1) food, drink or luxury consumer goods; (2) medicines or processes for the manufacture of medicine by mixing two or more medicines; (3) substances manufactured by a chemical process; (4) nuclear devices and products; (5) novel uses of chemical substances; and (6) inventions which threaten public health, morals or order. ${ }^{6}$

In the early 1980s, the U.S. government increased pressure on developing countries to enact stronger IPR laws. On November 4, 1985 President Reagan ordered U.S. Trade Representative Clayton Yeutter to initiate an investigation of Korea's IPR laws under Section 301 of the Trade Act. ${ }^{7}$ Behind the investigation loomed the threat of trade sanctions on some Korean exports to the United States. On July 21, 1986 the U.S. government suspended its Section 301 investigation; the Korean and U.S. governments made separate announcements to the effect that the Korean government had agreed to strengthen its patent laws. On December 31, 1986, the Korean National Assembly passed a new Patent Act (effective July 1, 1987) which extended product patent protection to new chemical and pharmaceutical products as well as to any new uses arising from these products. In addition, the new Act extended the product patent's term from 12 to 15 years from the grant of the patent or 18 years from the application date, whichever is longer. ${ }^{8}$ An extension of up to 5 years is permitted if other legal requirements, e.g. registration of pharmaceuticals, delay introduction of the product. Pharmaceutical products patented in the United States by U.S. nationals between 1980 and June 30, 1987, but not marketed in the United States or Korea during this period, were provided with ten years of patent protection. Such "pipeline" protection for pharmaceutical product patents was provided only to firms incorporated in the United States. Kim (1992: 9) reports that "515 out of 900 claims for protection of alleged pipeline products were granted." While some problems with enforcement remain, the 1986 revisions to the patent law have induced many Korean pharmaceutical firms to enter into licensing agreements and joint ventures with foreign pharmaceutical firms. Foreign firms and governments

${ }^{6}$ See Article 4 of the 1982 Patent Act. These exclusions are virtually identical to those found in Japan's patent law until 1975 when Japan amended its patent law.

7“Investigation Notice," F ederal Register, 50 (1985), 45,883.

${ }^{8}$ See Park (1987: 168) and Duvall (1988).

${ }^{9}$ The pipeline privilege granted to U.S. nationals led to disputes with the European Community (EC) which were settled in November 1993 when Korea agreed to extend pipeline protection to $221 \mathrm{EC}$-origin pharmaceutical and agro-chemical products. The protection is retroactive to July 1987. See "Korea-EC Poised to Bolster Economic Relations," Business Korea, December 1993, 37. 
have closely monitored IPR enforcement in Korea, and in April 1992 the USTR placed Korea on its "Priority Watch List" for failing to enforce IPRs adequately. ${ }^{10}$ In February 1993, the Korean government announced a package of measures to improve IPR enforcement, including increased prosecutorial resources and activities, which met with the approval of the U.S. government. Despite these measures, U.S. companies still have some complaints concerning the Korean patent system. In 1993 U.S. pharmaceutical companies were reporting delays in "obtaining registration approval from the Ministry of Health and Social Affairs for new drugs developed outside of Korea" and were concerned that confidential test data submitted to the Ministry were being disclosed or misused (United States Trade Representative, 1994: 191-192).

This stream of events stands in contrast to the evolution of chemical and pharmaceutical patent laws in Japan (Kawaura and La Croix, 1995). In 1955 Japan's Patent Office surveyed 1,352 companies, universities, and academic societies concerning the introduction of chemical product patents. The replies were evenly split between opponents and proponents of chemical product patents, and the government decided not to pursue the matter any further. In October 1970 the Japan Patent Association surveyed its member firms on whether they favored the introduction of chemical product patents. Approximately $60 \%$ of responses were favorable, while only $9 \%$ were negative. Given the strong support from the industry, the Japanese government began the process of changing Japan's laws to allow chemical and pharmaceutical product patents. The Japanese Diet enacted a product patent amendment in May 1975, with its provisions effective January 1, 1976.

Kawaura and La Croix (1995) used a stock market event study to investigate whether Japanese pharmaceutical firms gained from the introduction of product patents. For the 16 large firms in the sample, statistically significant positive excess returns totaling $25.82 \%$ were identified for the two-month period (April and May, 1975) when the patent legislation was moving through the upper and lower houses of the Diet. In this article we conduct a similar stock market event study for a portfolio of Korean pharmaceutical firms to investigate whether they gained or lost wealth due to Korea's introduction of pharmaceutical product patents.

\section{EVENT STUDY METHODOLOGY}

An event study investigates the effects of an event or a class of events by determining how the event affects the value of a firm. ${ }^{11}$ A change in the firm's value

${ }^{10} \mathrm{Clifford}(1988)$ noted complaints by U.S. pharmaceutical companies that only about a third of the approximately 1,000 patent applications filed by U.S. pharmaceutical companies have been approved by the government.

${ }^{11}$ Events can be a stock split, a dividend change, a merger and acquisition (M\&A) of firms, new regulations, accidents, and so on. 
is measured by the change in the rate of return on the firm's equity. ${ }^{12}$ When a company's stock realizes a significant excess (positive or negative) return during the "analysis period" surrounding the event announcement, it is inferred that the event had a significant impact on the company's future profitability. ${ }^{13}$

To measure the excess return we use a standard model that takes explicit account of market forces and trends as well as an individual stock's risk. The advantage of incorporating the return on the market portfolio is that it accounts for aggregate shocks affecting all companies, such as changes in oil prices. After controlling for the rate of return on the market portfolio, the residual component of the firm's rate of return reflects information relevant only to the particular firm and its industry.

Our empirical analysis builds on the following standard regression equation:

$$
R_{t}=\alpha+\beta R_{m t}+\mu_{t}
$$

where

$$
\begin{aligned}
& R_{t}=\text { rate of return on the stock in month } t \\
& R_{m t}=\text { rate of return on market portfolio in month } t \\
& \beta=\operatorname{COV}\left(R_{t}, R_{m t}\right) / \operatorname{VAR}\left(R_{m t}\right) \\
& \alpha=E(R)-\beta E\left(R_{m}\right) \\
& \mu_{t}=\text { disturbance term in month } t .
\end{aligned}
$$

We assume the distribution of $\mu_{\mathrm{t}}$ is $\mathrm{N}\left(0, \sigma^{2}\right)$. Parameter $\beta$ represents the systematic stationary risk of the stock. ${ }^{14}$

We adopt a regression model (Binder 1985a, 1985b) that enhances this specification by using dummy variables to capture the excess rate of return on a

${ }^{12}$ The definition of the rate of return is capital gain (loss) plus dividend payment divided by the last period's stock price.

${ }^{13} \mathrm{We}$ assume that the stock market is informationally efficient, that all publicly available information is incorporated into the price of a stock. This means that investors cannot earn excess returns from trading based on any publicly available information. Lee (1989) tests for weak-form efficiency on the Korea Stock Exchange using daily and monthly data on 60 heavily-traded stocks between January, 1983 and December, 1987. He finds that weak-form efficiency is rejected for daily data, but cannot be rejected for monthly data. Lee concludes that the Korean Stock Exchange "appears to be less weak-form efficient than the U.S. and other major European stock markets, but seems to be as weak-form efficient as the smaller European and other Less Developed Countries stock markets."

${ }^{14}$ Brealey and Myers (1991) offer a concise introduction to the relationship between risk and return in financial markets. 
firm's stock. Dummy variables are also used to capture the permanent changes in the parameters specified in (1) after the event takes place and to identify the excess return realized during the analysis period. We use the following specification to test for excess returns on a value-weighted portfolio of Korean pharmaceutical firms:

$$
R_{d t}=\alpha_{0}+\alpha_{1} J N_{t}+\alpha_{2} D U M_{t}+\beta_{1} R_{m t}+\beta_{2} R_{m t} D U M_{t}+\sum \Gamma_{j} D_{j t}+\mu_{d t}
$$

where

$\mathrm{R}_{\mathrm{dt}} \quad=$ rate of return on the portfolio of Korean pharmaceutical firms;

$\mathrm{AN}=1$ for January, $=0$ otherwise;

$\mathrm{DUM}_{\mathrm{t}}=1$ for every observation between the first news announcement month and the last observation in the sample;

$D_{j t}=1$ for the $j$ th month in the analysis period, $=0$ otherwise.

$\beta_{2}$ measures the extent of change in the covariance of the pharmaceutical rate of return and the market rate of return after the first news announcement. The JAN dummy variable is inserted to capture the so-called "January effect," where the prices of certain classes of stock exhibit systematic price changes during the month of January. ${ }^{15}$

A weakness of our analysis is that the event study methodology is more useful and reliable when employed in the investigation of a class of events than of a single event. Even when an excess return is detected in the neighborhood of a particular event, there always remains some possibility that it was due to some factor other than the event under investigation. In a multi-event study, the probability of coincidental events declines as the number of event observations increases. Since our analysis is a study of a single event, the 1985-1986 patent law change, this limitation is clearly present and should be noted. Moreover, the passage of a law does not imply that the authorities will vigorously enforce the law. If investors expect that authorities will not allocate sufficient resources to pursue offenders of the law or that courts will be biased towards Korean firms, then passage of the new law may have little or no effect on the rate of return to Korean pharmaceutical stocks.

${ }^{15}$ Small firm returns are significantly higher than large firm returns during January in both the United States and Japan. Tong (1992) finds that the January effect is not present in the Korea Stock Exchange. Gultekin and Gultekin (1983) survey evidence on the existence of the January effect for other countries. 


\section{STOCK MARKET DATA AND THE ANALYSIS PERIOD}

\section{A. Stock M arket Data}

All data on Korean stock prices were obtained from the Korea Stock Exchange. ${ }^{16}$ Reliable rate of return data on individual pharmaceutical stocks were unavailable, so we restricted our analysis to a portfolio of pharmaceutical stocks listed on the Korea Stock Exchange (KSE). The pharmaceutical portfolio constituted $2.57 \%$ of the total KSE market value in 1985 and 1.41\% in 1986 (Korea Stock Exchange, 1990). We use the KSE pharmaceutical stock price index to calculate a monthly rate of return for the pharmaceutical industry portfolio from January 1980 to December $1989 .{ }^{17}$ Since the rate of return on pharmaceutical stocks is likely to covary with the market rate of return, we also calculate the rate of return on all stocks in the KSE from the Korea Composite Stock Price Index (KCSPI). The KCSPI and the pharmaceutical stock index are calculated by aggregating the market capitalization of all listed companies. Unfortunately, neither index is adjusted to reflect dividend payments. Thus using these indices to calculate rates of return biases the rate of return downward during the months in which dividends are paid.

The market portfolio exhibited only small gains between 1980 to late 1985 . In late 1985 it began a steady climb which did not end until late 1988. From late 1988 through the end of 1989 the portfolio remained relatively constant while fluctuating some in value. The pharmaceutical portfolio exhibited similar behavior with the exception of two periods: late 1982 to mid-1984 and late 1985 to the end of 1986 . From November 1982 to June 1984, the pharmaceutical index increased 140.97\%, while the market index increased 9.29\%. From October 1985 to December 1986, the pharmaceutical index fell $10.31 \%$, while the market index increased $94.92 \%$.

\section{B. The Analysis Period}

Choice of the analysis period is critical for an event study. Since an event study attempts to identify the response of investors to a particular event, it is important that the researcher identify the period during which unanticipated information is revealed to investors. If the analysis period is incorrectly identified, the event study will fail to reveal the full impact of the event on the company's future profitability and is more likely to pick up the effects of other events relevant to the firm.

When an event takes a strictly unanticipated form, such as an airplane crash, specification of the analysis period is a relatively simple matter. Determining the date at which investors begin to assign a higher probability to a new legal environment is a

${ }^{1}$ Since we restrict our analysis to pharmaceutical firms listed on the Korean Stock Exchange, our analysis omits small unlisted pharmaceutical firms.

${ }^{17}$ The rate of return is calculated as the difference in the log of the portfolio in the current period and the log of the portfolio in the previous period. 
more difficult task. This is because information about the probability of a change in the law is revealed over a period of time, and it is difficult for the analyst to judge a priori which information is significant. The analysis period may encompass the time frame between initial proposals for a change in the law and the date when the legislation receives final approval. Binder (1985a) reached the pessimistic conclusion that stock returns are ineffective in measuring the effects of changes in the legal environment when the dates on which market expectations change cannot be carefully specified. Other analysts (Dann and James, 1982) are more optimistic that they have successfully determined the announcement date and have derived significant excess returns resulting from regulatory or legislative changes.

To determine the event date, we follow the methodology laid down by other regulatory event studies: Possible event dates are identified from news articles in major business newspapers in the United States and Korea. Possible candidates for the beginning and end of the analysis period include the Reagan administration's announcement of the USTR investigation on November 4, 1985; the July 21, 1986 announcement of the agreement between the two governments; and the December 31, 1986 passage of the patent law amendments by the National Assembly. We formulate two analysis periods, both of which begin with the Reagan administration's announcement of the Korean IPR investigation by the USTR in November 1985. Korean investors must have given careful consideration to how the Korean government would respond to such a strong move by the United States government. Rational investors may have expected that the Korean government would be forced to make concessions due to the importance of the United States market to Korean exporters in other industries. Our first analysis period runs from November 1985 to December 1986, when the new patent law was enacted. The second analysis period ends in August 1986, one month after the announcement by the two governments of an agreement on a new patent law for Korea. We believe that the close relationship between Korea's president and legislative leaders during this period meant that investors could confidently predict the scope and timing of a new law and could incorporate expectations of its effects into stock prices shortly after the July 1986 announcements by the two governments of their agreement. On the other hand, one could argue that the movement toward democracy in Korea and the possibility of disruptive incidents harming United States-Korean relations left substantial residual uncertainty until the Korean legislature passed the new patent law in December 1986. We experiment with both specifications of the analysis period.

\section{EMPIRICAL RESULTS AND INTERPRETATION}

We employed the event study methodology to determine whether the 1986 introduction of the chemical product patent increased the value of Korean pharmaceutical manufacturers. Before estimating equation (2), we conducted pretests 
on the rate of return to the market portfolio and to the drug portfolio to determine whether they are stationary series. Using augmented Dickey-Fuller tests (Engle and Granger, 1991: Ch. 1), we find that both series are stationary. ${ }^{18}$ This allows us to proceed with ordinary least squares estimation of equation (2).

Two specifications of equation (2) are estimated to examine both analysis periods discussed above. Since disturbance variance often increases during event periods (Boehmer et. al., 1991), it is important that the estimation procedure account for the possible presence of heteroskedasticity. Our estimation uses White's (1980) heteroskedastic-consistent covariance matrix estimation to correct the ordinary least squares estimates for an unknown form of heteroskedasticity.

Table 1. Excess Returns Using Monthly Dummy Variables

\begin{tabular}{|c|c|c|c|c|}
\hline \multirow[b]{2}{*}{ Variable } & \multicolumn{2}{|c|}{ Analysis Period 1} & \multicolumn{2}{|c|}{ Analysis Period 2} \\
\hline & Est. Coeff. & t-statistic & Est. Coeff. & t-statistic \\
\hline Constant & .016 & $3.29 * *$ & .016 & $3.27 * *$ \\
\hline Market Return $\left(\beta_{1}\right)$ & .369 & $2.39 * *$ & .371 & $2.40 * *$ \\
\hline \multicolumn{5}{|l|}{ Interactive } \\
\hline Market Return $\left(\beta_{2}\right)$ & .570 & $2.41 * *$ & .527 & $2.36 * *$ \\
\hline Post-Event Dummy & -.015 & -1.36 & -.016 & 1.55 \\
\hline January Dummy & -.006 & -0.26 & -.005 & -0.20 \\
\hline Nov. 1985 & -.082 & $-8.06 * *$ & -.080 & $-8.43 * *$ \\
\hline Dec. 1985 & -.108 & $-7.80 * *$ & -.104 & $-7.96 * *$ \\
\hline Jan. 1986 & .016 & .68 & .015 & .66 \\
\hline Feb. 1986 & -.082 & $-6.19 * *$ & -.079 & $-6.25 * *$ \\
\hline March 1986 & -.081 & $-4.41 * *$ & -.076 & $-4.39 * *$ \\
\hline April 1986 & -.054 & $-3.31 * *$ & -.050 & $-3.22 * *$ \\
\hline May 1986 & -.037 & $-3.80^{* *}$ & -.036 & $-4.04 * *$ \\
\hline June 1986 & -.140 & $-6.20 * *$ & -.133 & $-6.33 * *$ \\
\hline July 1986 & -.055 & $-3.64 * *$ & -.051 & $-3.56 * *$ \\
\hline Aug. 1986 & -.047 & $-4.67 * *$ & -.045 & $-4.85 * *$ \\
\hline Sept. 1986 & -.007 & -0.59 & & \\
\hline Oct. 1986 & .03 & 1.59 & & \\
\hline Nov. 1986 & -.037 & $-3.22 * *$ & & \\
\hline Dec. 1986 & -.055 & $-4.44 * *$ & & \\
\hline $\mathrm{R}^{2}$ Adj. & \multicolumn{2}{|c|}{.24} & \multicolumn{2}{|c|}{.26} \\
\hline DW & \multicolumn{2}{|c|}{1.66} & \multicolumn{2}{|c|}{1.69} \\
\hline
\end{tabular}

Notes: $* *$ denotes statistical significance at the 5 percent level.

${ }^{18}$ The coefficient on the lagged level was statistically significant from zero at the five percent level. 
The results from our first analysis period (November 1985 to December 1986) are displayed in Table 1. Twelve of the fourteen estimated coefficients on the dummy variables representing the analysis period are negative, and all (but one) negative coefficients are statistically significant at the five percent level. The sum of the fourteen estimated coefficients is -.74 , representing a $74 \%$ decline in the value of the drug portfolio over the analysis period. An F-test that the sum of the estimated coefficients equals zero rejects the null hypothesis at the one percent level. ${ }^{19}$ If we consider the dummy variables in the analysis period individually, the three largest estimated coefficients are November 1985 (-.082), December 1985 (-.108), and June 1986 (-.14). The first two dummy variables are the month of and the month after the Reagan administration's announcement of the USTR investigation. The third dummy is the month before the announcement by the two governments of an agreement to resolve the dispute. In other words, about $45 \%$ of the stock market's response is concentrated around the two dates in which important information is revealed to the market.

The estimated coefficient $\left(\beta_{1}=.369\right)$ on the market return is less than one, which is consistent with estimated Betas for American, Japanese, and European pharmaceutical firms. The magnitude of the estimated Beta is lower than our estimated Betas for individual Japanese pharmaceutical firms which ranged from .58 to 1.13 (Kawaura and La Croix, 1995). Our results also indicate that after the start of the event period (November 1985), the estimated Beta for the pharmaceutical portfolio increased to $.939\left(\beta_{1}+\beta_{2}\right)$, thereby linking variation in pharmaceutical returns more closely to variation in overall market returns.

The model's estimated coefficients could be biased if nonsynchronous trading in the pharmaceutical stocks frequently occurs. We follow Mitchell (1989) in using Dimson's technique for testing the potential bias from nonsynchronous trading. We run our model using $R_{m, t-1}, R_{m, t-2}, R_{m, t-3}$, and $R_{m, t+1}$ as additional independent variables and find that the excess returns generated by the augmented regressions are broadly consistent with the estimates reported in Table $1 .^{20}$

Results from the second analysis period (November 1985 to August 1986) are also displayed in Table 1. The results are broadly similar to those from the first analysis period. Nine of the ten estimated coefficients on the dummy variables representing the analysis period are negative, and all negative coefficients are statistically significant from zero at the five percent level. The sum of the ten estimated coefficients is -.64 , representing a $64 \%$ decline over this analysis period. An F-test that the sum of the estimated coefficients equals zero rejects the null hypothesis at the one percent level. ${ }^{21}$ If we consider the dummy variables in the analysis period individually, the three largest estimated coefficients are, as in the first specification, November 1985 (-.080), December 1985 (-.104), and June 1986 (-.133). The

${ }^{19} \mathrm{~F}(1,100)=24.71$

${ }^{20}$ The augmented regression results are available from the authors on request.

${ }^{21} \mathrm{~F}(1,104)=30.60$ 
cumulative excess return for these three months is $-31.7 \%$. In other words, about $50 \%$ of the stock market's response is concentrated around the two dates in which important information is revealed to the market.

Results from both analysis periods are independent of the other control variables included in the regression specification. The size and statistical significance of the estimated coefficients on the monthly dummies do not change substantially when dummy variables capturing the January effect or the post-event observations are omitted from the regression.

Table 2 reports results for regression specifications which use a single dummy variable to represent the event period rather than individual dummy variables for each month in the analysis period. For the first specification of the analysis period, the estimated coefficient on the event dummy variable is -.05 which is statistically significant at the five percent level. Over the 14-month analysis period, the cumulative excess return is $-70 \%$, which is close to the cumulative excess return ($74 \%$ ) computed from estimates in Table 1. For the second specification of the analysis period, the estimated coefficient on the event dummy variable is -.061 which is statistically significant at the five percent level. Over the ten-month analysis period, the cumulative excess return is $-61 \%$, which is close to the cumulative excess return $(-64 \%)$ computed from estimates in Table 1 . We conclude that this alternative specification supports the baseline results reported in Table 1.

Table 2. Excess Returns Using a Period Dummy Variable

\begin{tabular}{lcc}
\hline Variable & $\begin{array}{c}\text { Estimated Coefficient } \\
\text { for Analysis Period } 1 \\
\text { (t-statistic) }\end{array}$ & $\begin{array}{c}\text { Estimated Coefficient } \\
\text { for Analysis Period 2 } \\
\text { (t-statistic) }\end{array}$ \\
\hline Constant & .015 & .015 \\
Market Return $\left(\beta_{1}\right)$ & $(3.10)^{* *}$ & $(3.07)^{* *}$ \\
Interactive Market Return $\left(\beta_{2}\right)$ & .382 & .383 \\
& $(2.45)^{* *}$ & $(2.46)^{* *}$ \\
January Dummy & .376 & .434 \\
Post-Event Dummy & $(1.74)^{*}$ & $(2.01)^{* *}$ \\
Event Period Dummy & .004 & .006 \\
& $(.20)$ & $(.27)$ \\
\hline $\mathrm{R}^{2}$ Adj. & -.009 & -.013 \\
DW & $(-.82)$ & -.061 \\
& -.050 & $(-3.94)^{* *}$ \\
\hline
\end{tabular}

Notes: $*$ denotes significance at the 10 percent level, $* *$ at the 5 percent level. 
The event study results are not surprising, as R\&D expenditures by the Korean pharmaceutical industry have been unimpressive. Only US\$58 million was spent on R\&D by the entire industry during 1990 . While this represents a $25 \%$ annual increase in R\&D expenditures since 1988 , it contrasts unfavorably with the US\$6,537 million spent by United States pharmaceutical firms on R\&D in 1988 or the US\$2,273 million spent by Swiss pharmaceutical firms in 1988 (Japan Pharmaceutical Manufacturers Association, 1990: 49). Even leading Korean pharmaceutical firms invest less than $4 \%$ of sales in R\&D. For example, Dae Wong Pharmaceutical Co. spent only 3.2\% of its US\$110 million in sales on R\&D in 1990, while Chong Kun Dang spent only $3.8 \%$ of its US $\$ 134$ million in sales on R\&D in 1990. By contrast, in 1988 United States firms spent $13.9 \%$ of sales revenue on R\&D, Japanese firms $10.74 \%$, and German firms $17.4 \%$.

The low R\&D expenditures are reflected in Korea's pharmaceutical product patent statistics. Approximately 443 pharmaceutical products were patented in Korea between the change in the patent law (July 1, 1987) and the end of 1990. None of these products were developed in Korea (Jae-Keum, 1991:57). Table 3 provides an international comparison of the percentage of employees working in R\&D. Inspection indicates that Korean firms employ only about $2 \%$ of their staff in R\&D activities, while pharmaceutical firms in developed countries engage from $9 \%$ to $24 \%$ of their staff in R\&D activities. Leading Korean firms have, however, been increasing their R\&D expenditures rapidly since 1990 (Jae-Keum 1991). If the rapid increases in R\&D expenditures continue, the R\&D "gap" could close within the next decade, allowing Korean firms to produce commercially viable pharmaceutical products at the beginning of the twenty-first century.

Table 3. R\&D Employees in International Pharmaceutical Industries

\begin{tabular}{lccc}
\hline Country & $\begin{array}{c}\text { Total Number } \\
\text { of Employees }\end{array}$ & $\begin{array}{c}\text { Total Number } \\
\text { of R\&D Empl. }\end{array}$ & $\begin{array}{c}\text { Percentage of } \\
\text { R\&D Employees }\end{array}$ \\
\hline USA (1988) & 179,420 & 41,520 & $23.14 \%$ \\
Japan (1988) & 121,742 & 22,627 & $18.59 \%$ \\
W. Germany (1987) & 75,075 & 14,200 & $18.91 \%$ \\
Italy (1986) & 64,582 & 6,171 & $9.56 \%$ \\
Korea (1989) & 51,985 & 913 & $1.76 \%$ \\
\hline
\end{tabular}

Data Sources: Japan Pharmaceutical Manufacturers Association (1990:4-5); P harmacy in K orea 1990 (1990:57).

\section{CONCLUSION}

Our central conclusion is that the pressure by the United States government on the Korean government to adopt strong product patent laws occurred when Korea's 
pharmaceutical industry was incapable of developing new internationally marketable drugs. The resultant loss of wealth in the pharmaceutical industry is reflected in the performance of the drug industry stock portfolio from November 1985 to December 1986. While the value of the market portfolio was rapidly increasing, the weighted index of pharmaceutical stocks declined slightly. The cumulative decline in the pharmaceutical stock portfolio relative to the market portfolio was an astounding -74 percent, which is the sum of all estimated coefficients on the dummy variables representing individual months in the analysis period.

Over the last decade the United States and the European Union have made demands that middle-income and developing countries take measures to provide stronger protection for intellectual property, including pharmaceuticals, or risk trade sanctions. Developing countries have resisted these demands for both political and economic reasons. The Korean experience provides evidence that wealth losses are potentially large and may be the driving force behind opposition to the foreign pressure. The 1994 GATT treaty may change this game between developed and developing countries, as it established strong minimum IPR standards for all GATT signatories. Strengthened IPRs in the poorest developing countries present economists with more opportunities to examine the impact of stronger IPR laws on the wealth and welfare of developing countries. Clearly, the impact is likely to vary by industry, the initial state of R\&D activity, industry structure, and patterns of industrial conduct. A country close to developed country status, such as Singapore, may experience welfare gains when it adopts stricter IPR laws, while a country in the early stages of development (such as Indonesia) is likely to experience welfare losses when it strengthens IPR laws (Maskus and Konan, 1994). Our findings for Korea provide preliminary evidence that the transition to stronger IPR laws in the developing countries may generate further economic losses for some countries and increased political controversy.

\section{REFERENCES}

Binder, J. J., "Measuring the Effects of Regulation with Stock Price Data," Rand J ournal of Economics, Summer 1985 (a), 167-83.

, "On the Use of the Multivariate Regression Model in Event Studies," J ournal of Accounting Research, Spring 1985 (b), 370-83.

Boehmer, E., Musumeci, J., and Poulsen, A. B., "Event-Study Methodology Under Conditions of Event-Induced Variance," J ournal of Financial Economics, December 1991, 253-272.

Brealey, R. and Myers, S., Principles of Corporate Finance, 4th ed. New York: McGraw-Hill, 1991.

Clifford, M., "Patent Drugs Abuse," Far Eastern Economics Review, June 30, 1988, 48-49.

Dann, L. Y., and James, C. M., "An Analysis of the Impact of Deposit Rate Ceilings on the Market Value of Thrift Institutions," J ournal of F inance, December 1982, 
$1259-75$

Duvall, D. K., "Fair Trade and the Protection of Intellectual Property Rights in the United States-Korean Economic Relations," Law/Technology, 1st Quarter 1988, 18-35.

Engle, R. F., and Granger, C. W. J., Long-Run Economic Relationships: Readings in Cointegration, New York: Oxford University Press, 1991.

Gultekin, M. N., and Gultekin, N. B., "Stock Market Seasonality: International Evidence," J ournal of F inancial Economics, December 1983, 469-81.

Jae-Keum, Jung, "Prescription for R\&D," Korea Economic Report, August 1991, 56-57.

Japan Pharmaceutical Manufacturers Association, Data B ook 1990, Tokyo, 1990.

Kawaura, A., and La Croix, S. J., "Japan's Shift from Process to Product Patents in the Pharmaceutical Industry: An Event Study of the Impact on Japanese Firms," Economic Inquiry, January 1995, 88-103.

Kim, M. H., "Recent Developments in Intellectual Property in Korea: Theory and Practice," unpublished manuscript, 1992.

Korea Stock Exchange, Korea Composite Stock P rice Index, Seoul 1990.

"Korea-EC Poised to Bolster Economic Relations," Business Korea, December 1993, 37.

La Croix, S. J., "The Political Economy of Intellectual Property Rights in Developing Countries," in J. Roumasset and S. Barr, eds., The Economics of Cooperation: East Asian Development and the Case for Pro-Market Intervention, Boulder, Colorado: Westview Press, 1992.

Lee, S. C., "Tests of Weak-Form Stock Market Efficiency on the Korea Stock Exchange," unpublished Ph.D. dissertation, Kent State University, 1989,

Maskus, K. E., "Normative Concerns in the International Protection of Intellectual Property Rights," World E conomy, September 1990, 387-409.

Maskus, K. E., and Konan, D. E., "Trade-Related Intellectual Property Rights: Issues and Exploratory Results," in A. V. Deardorff and R. M. Stern, eds., Analytical and Negotiating Issues in the Global Trading System, Ann Arbor: University of Michigan Press, 1994.

Mitchell, M. L., "The Impact of External Parties on Brand-Name Capital: The 1982 Tylenol Poisonings and Subsequent Cases," Economic Inquiry, October 1989, 601-18

Office of Patents, Republic of Korea, Laws of Industrial P roperty, Seoul, 1981.

Park, A. Y., "International Trade - Agreement Between the United States and the Republic of Korea Concerning Insurance Market Access and Intellectual Property Protection in the Republic of Korea," Harvard International Law J ournal, Winter 1987, 166-174.

Pharmacy in K orea 1990, Seoul: Yakup Shinmoon, 1990.

Tong, Wilson H. S., "An Analysis of the January Effect of United States, Taiwan and South Korean Stock Returns," Asia Pacific J ournal Of M anagement, October 1992, 189-207. 
United States Trade Representative, 1994 National Trade Estimate Report on F oreign Trade Barriers, Washington, D. C.: Government Printing Office, 1994.

West, J., "Evolving Industrial Property Law and Transfer of Technology in the Republic of Korea," Texas International Law J ournal, Winter 1983, 127-149.

White, H., "A Heteroskedasticity-Consistent Covariance Matrix Estimator and a Direct Test for Heteroskedasticity," Econometrica, May 1980, 817-838.

Mailing Address: Professor Sumner J. La Croix, Department of Economics, University of Hawaii, Honolulu, Hawaii 96822, U. S. A.

Mailing Address: Dr. Akihiko Kawaura, Department of Economics, Otaru U niversity of Commerce, O taru, Hokkaido 047, J APAN 